\title{
Separation of Powers in the Kuwaiti Criminal Justice System: A Case Study
}

\author{
Abdulrahman F S H Alhajri
}

\begin{abstract}
Discussions of the Separation of Powers (SOP) tend to be related to the administrative state, at the expense of the criminal state. This research addresses the question of separating powers within the criminal justice system of Kuwait, examining the function of this division and the structures that are designed to protect the rights of citizens. Despite being regulated according to democratic principles, the criminal justice system of Kuwait has been described as excessively controlled by executive bodies. Currently, there appears to be a lack of research explaining how numerous criminal justice bodies in Kuwait can effectively promote the principles of freedom, democracy, and equality before the law. The proposed research aims to provide insights into the SOP between institutions and to assess its effectiveness in addressing the principles stated in the Constitution of Kuwait. The origins of the modern Kuwaiti criminal justice system will also be explored, with a focus on British Jurisdiction (as a past influence) and French, Egyptian and Islamic law (as continuing influences). This development history makes Kuwait an excellent example of the diffusion of law, which, although it has been investigated widely, is still a topic of interest among modern researchers, alongside human rights and their protection through the criminal law system. This is one of the first studies to discuss the SOP in the Kuwaiti criminal justice system as a mixed phenomenon that can influence the protection of Kuwaiti citizens' human rights at each stage of law enforcement and prosecution.
\end{abstract}

Keywords: Separation of Powers, Criminal Justice System, law.

\section{Introduction}

The Separation of Powers (SOP) in a criminal justice system can be regarded as a method of protecting citizens' rights

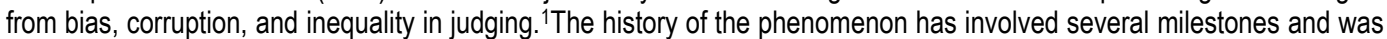
the product of the minds of multiple notable figures. For example, Aristotle introduced a number of constitution-related ideas in his Politics, especially in books two - seven, which considered citizenship, types of regimes, and constitution. With respect to SOP, the author distinguished between "the deliberative body, the magistracies and the judges" in book four, suggesting that such separation could prevent absolute power. ${ }^{2}$ Furthermore, in his criticism of the then-existing patriarchal system of power, Locke focused on SOP in the context of legislation and formulated the "principle of legislative supremacy $\ldots$ in the sense that it envisions the legislature as having an initiating place on the assembly line of law-making/law enforcement" 3 , arguing that an "authority that is able to give laws to others must necessarily be the superior of the latter." It can be suggested that Locke did not only try to separate the judiciary system; he also implied that there was a hierarchy of the branches of power, with judiciary being the "supreme power." ${ }^{5}$ However, the principle of separating powers was clearly formulated by Montesquieu, who focused on the idea of SOP between "the three sorts of power: the legislative; the executive in respect to things dependent on the law of nations; and the judiciary in regard to matters that depend on the civil law." 6 Montesquieu based his view on a comprehensive analysis of a variety of systems, including ancient ones (for example, those of Romans and Barbarians) ${ }^{7}$ and those that were contemporary at the time (for example, that of

1David Samuels, 'Separation of Powers' in C Boix and SC Stokes (eds), The Oxford Handbook of Comparative Politics (OUP 2009) 703, 706.

${ }^{2}$ Aristotle, Politics (H. Rackham [transl]) (Cambridge University Press, 1932), at 1297b-1298a. See also Gerard Conway, 'Recovering a Separation of Powers in the European Union' (2011) 17 European Law Journal 304, 306.

3 Jeremy Waldron, 'Separation of Powers in Thought and Practice' (2013) 54 Boston College Law Review 433, 441.

4John Locke, Two Treatises On Government (Industrial Systems Research 2009) at 188.

5/bid.

${ }^{6}$ Charles Baron De Montesquieu, The Spirit of Laws (Cosimo 2011) at 151.

7 Ibid. at 95 . 
England). ${ }^{1}$ While not the first to pinpoint the idea of SOP, Montesquieu is believed to be the first person to fully and explicitly formulate the idea of tripartite SOP, aiming to "prevent the concentration of all power in the hands of a single ruler." ${ }^{\text {It }}$ is also noteworthy that the practice of using SOP in Islamic countries started with Umar ibn Al-Khattab (634-644 AD), who was the second Caliph of Islam. He may have been the first person to implement a form of SOP, in particular, to isolate the judiciary from the executive branch. ${ }^{3}$ This outcome was achieved by appointing both judges and governors in the provinces, both of which were supposed to be under the supervision of the Caliph. ${ }^{4}$ This measure ensured their independence from each other, although, eventually, the judiciary depended on the Caliph. Thus, the Islamic roots of SOP can also be found, and they are related to the practice of SOP.

It can be suggested that the discussions around the SOP tend to be related to administrative or public law in the majority of cases. In her study, Barkow states that although scholars have written many works on the SOP in a state, they "have wholly ignored the criminal state". ${ }^{5}$ Barkow mentions at least a dozen works that illustrate her point, explaining that she had analysed only a small sample of the literature. ${ }^{6}$ It is noteworthy that the majority of the works that she mentions were written in the previous century. Still, the issue appears to have been carried into the new century: the consideration of the administrative side of SOP is exemplified by multiple works, including those by Koven, Bruff, Kamali, and Tribe. ${ }^{7}$ However, the criminal-matters perspective seems to be rarely mentioned. Articles by Haljan and Nelson and Ringsmuthcan be used to illustrate works that do mention it, but such examples seem to be underrepresented, and they do not focus on the topic. ${ }^{8}$ At the same time, it is important to achieve the SOP in the field of justice as it permits the judicial system to be relatively independent and it improves its legitimacy, which is highlighted, for example, by Hall. ${ }^{9}$ An analysis of Ashworth's conclusions can be interpreted to suggest that this importance also correlates with a history of challenges in ensuring the judiciary's independence, which the author recognises as "failures of state-led criminal justice."10 These failures can be the result of the difficulties the judiciary experience in resisting external pressures, which the government is supposed to reduce, if not nullify. As suggested by Ashworth, "it should remain the responsibility of the state towards its citizens to ensure that justice is administered by independent and impartial tribunals."11 Apart from that, Barkowdemonstrates that the administrative and criminal perspectives on the SOP are noticeably different, and in practice, few safeguards, including individual rights as delineated in the Constitution, are applied to the latter. ${ }^{12}$ Thus, the author points out the tendency to ignore criminal-matter SOP, indicating the need to acknowledge and change the situation, which the proposed paper aspires to do.

The current research aims to examine how the SOP in the criminal justice system of Kuwait contributes to addressing citizens' rights, with the focus on the principles mentioned in the Constitution of Kuwait. Article 50 of the Kuwaiti Constitution declares the principle of SOP at the level of the state: "In conformity with the provisions of the Constitution the system of

\footnotetext{
$1 /$ bid. at 151.

2 Anthony Murphy and Alan Stoica, 'Sovereignty: Constitutional and Historical Aspects' (2015) 2Bulletin of the Transilvania University of Braşov219, 224.

3Myra Williamson, 'The diffusion of Western Legal Concepts in Kuwait: Reflections on the State, the Legal System, and Legal Education' in S Farran, J Gallen and C Rautenbach (eds), The Diffusion of Law: The Movement of Laws and Norms around the World (Routledge 2016) at 32.

${ }^{4}$ Sharifah Hayaati Syed Ismail al-Qudsy and Asmak Ab Rahman, 'Effective Governance in the Era of Caliphate 'Umar Ibn Al-Khattab (634-644)' (2011) 18 European Journal of Social Sciences 612, 620; see also Ata urRehman, Mazlan Ibrahim and Ibrahim Abu Bakar, 'The Concept of Independence of Judiciary in Islam' (2013) 4 International Journal of Business and Social Science 67, 68.

${ }^{5}$ Rachel Barkow, 'Separation of Powers and the Criminal Law' (2006) 58 Stanford Law Review 989, 989.

6/bid. at 992.

7 Steven Koven, 'Separation of Powers, Rule of Law, and the Bush Administration' (2009) 11 Public Integrity 347-361; see also Harold Bruff, Balance of Forces: Separation of Powers Law in the Administrative State.(Carolina Academic Press 2006) 1-526; Mohammad HashimKamali, 'Separation of Powers: An Islamic Perspective' (2014) 5/slam and Civilisational Renewal 471-488; Laurence Tribe, 'Transcending the Youngstown Triptych: A Multidimensional Reappraisal of Separation of Powers Doctrine' (2016) 126 The Yale Law Journal Forum 86-106.

8 Done Haljan, Separating Powers: International Law Before National Courts, (Springer 2013) 230-231; see also Tom Clark, 'The Separation of Powers, Court Curbing, and Judicial Legitimacy' (2009) 53 American Journal of Political Science 971-989.

${ }_{9}^{9}$ Matthew Hall, 'The Semiconstrained Court: Public Opinion, The Separation Of Powers, And The U.S. Supreme Court's Fear Of Nonimplementation' (2013) 58 American Journal of Political Science 352, 352-353; see also Clark, supra (n 15) 971, 971-989.

${ }^{10}$ Andrew Ashworth, 'Responsibilities, Rights, and Restorative Justice' (2002) 42 British Journal of Criminology 578, 590.

11 Ibid.at 591.

12Barkow, supra (n 12) 989, 1031.
} 
government shallbe established on the basis of separation and cooperation of powers", and moreover, "No Authorityshall be allowed to waive all or part of its jurisdiction as prescribed in thisConstitution". ${ }^{1}$ Still, the legal background for the SOP principles in the state is not derived solely from the Constitution. Much attention will be paid to discussing the effect of British Jurisdiction(as a past influence), as well as the continuing impact of the French and Egyptian law on the development of the criminal justice system in a country that gained independence from the United Kingdom in 1961. ${ }^{2}$ Furthermore, it is important to take into account the fact that Kuwait is an Islamic country, but that Muslim law has a direct impact on only the country's family law. ${ }^{3}$

The proposed study will examine the extent to which an effective SOP exists in the Kuwaiti criminal justice system. The first step is a general overview of the intricate net of functions that are shared and divided between institutions and personnel, and which are typical of the country's criminal justice system. The second step is a discussion of critical issues in the system and its functioning, involving the question of the protection of citizens' rights. The Kuwaiti criminal justice system can be described as mixed in its origins. ${ }^{4}$ Also, it is not fully protected from over-bureaucratisation, dishonest or wrongful conduct, possible biases, and unfairness. ${ }^{5}$ Due to the significance of these challenges, the analysis of police structures, prosecutors' responsibilities, and the judiciary, with a focus on the role of Article 50 in determining the SOP, are the most important parts of this research.

Much attention should be paid to the role of prosecutors and the prosecutorial process in Kuwait, which are influenced by the traditions of French law. Discussion of this process allows conclusions to be drawn regarding the effectiveness of the SOP in Kuwait, with the focus on conducting unbiased crime-control procedures. The analysis should include a discussion of those aspects of the criminal justice system adopted in Kuwait that can lead to a reduction in the number of crimes against citizens' rights in the country. ${ }^{6}$ In this context, the focus is on the resources that are available to representatives of different branches of the system for the purpose of organising an effective prosecutorial process and litigation. Finally, conclusions and recommendations need to be provided regarding the role of SOP in the criminal justice system in protecting Kuwaiti citizens' rights. The recommendations will be formulated referring to the analysis of the criminal justice system's mixed structure.

A certain typology of SOP assessment criteria is also proposed for the study. A most significant criterion is the level of the independence of the judiciary, which can be assessed by pinpointing the instances of supervision and control performed by other branches of power. In particular, in Kuwait, the procedures that are related to the appointments of judges imply a lack of judiciary independence from the executive power. ${ }^{7}$ Thus, the procedures of the judiciary, including the appointment and removal of judges, can be reviewed to assess SOP. Apart from that, the management of cases, especially those related to political crimes, the protection of the rights of offenders and inmates, and the work of the appeal system, might signal independence issues. If miscarriages of justice can be pinpointed, they should also be analysed for external pressures. Finally, police conduct, including interrogation, is of interest for the study.

It should also be mentioned that the proposed study refers to the work of Barkow. The article considers the context of the United States, and Barkow notes that although the risk of abuse and prejudice can be reduced with SOP, "more stringent enforcement of the separation of powers in criminal cases" is required in the United States. ${ }^{8}$ As a result, Barkow's work is not directly connected to the topic of the current research, but it may be helpful to consider the research and practice in the field of SOP in several countries to form the argument for Kuwait.

${ }^{1}$ Constitution of Kuwait, 1962, art. 50.

2 Nathan Brown, 'Mechanisms of Accountability in Arab Governance' (United Nations, 2001) accessed 25 December 2016, 1, 8; see also Ahmad Hijazi, 'Kuwait: Development from a Semitribal, Semicolonial Society to Democracy and Sovereignty' (1964) 13 The American Journal of Comparative Law 428, 437; Daniel Treisman, 'The Causes of Corruption: A Cross-National Study' (2000) 76 Journal of Public Economics 399, 403.

${ }^{3}$ Herbert Liebesny, The Law of the Near and Middle East: Readings, Cases, and Materials (SUNY Press 1975), 110; Nathan Brown, The Rule of Law in the Arab World, (Cambridge University Press 2006) at 132.

4Williamson, supra (n 10) at 41.

${ }^{5}$ Brown, supra (n 22) 159.

6Williamson, supra (n 10) at 36.

${ }^{7}$ Alkarama Foundation, 'Kuwait: Report submitted to the Human Rights Committee in the context of the third periodic review of Kuwait' (Alkarama Foundation, 2016) 12. Accessed 22 March 2017.

${ }^{8}$ Barkow, supra (n 12) at 990. 


\section{The Role of Separating Powers between Institutions in the Criminal Justice System}

Throughout its existence, the idea of SOP was adopted in a number of contexts, which allows conclusions to be drawn about its theoretical and practical value. A very early example of the use of SOP is the adoption of some of its elements (in particular, the separation of the judiciary from the executive branch) by Umar ibn Al-Khattab (634-644 AD). ${ }^{1}$ There is some debate on the topic: according to Rehman, Ibrahim, and Bakar, ${ }^{2}$ one of the schools of thoughts argues that at that time of Umar ibn Al-Khattab, the judiciary was merged with the executive branch (which means that neither of them is controlling the other; they were just parts of the same branch). However, Rehman, Ibrahim, and Bakar highlight the evidence ${ }^{3}$ which indicates that the caliphs did delegate part of their power to judges. Apart from that, the authors focus on the principles of justice from the Quran, ${ }^{4}$ suggesting that in order to achieve justice, fairness, equity, and impartiality promoted by it, the judiciary needs to be independent. ${ }^{5}$ The authors present a clear and logical argument, which is based on historical evidence and the analysis of Quran. Therefore, the Islamic roots of SOP practice may be present.

In the British and French law systems (which both developed their own monarchy-based SOP versions), the concept of the SOP was adopted in the wake Montesquieu's argument regarding the potential of this system to protect citizens' rights. ${ }^{6}$ It is noteworthy that France's legal-matters SOP refers back to the pre-revolutionary "parlements" that performed "regulated resistance," which modified the relationships between the monarchy and the nobility, according to Goldoni. ${ }^{7}$ In addition, the SOP has been demonstrated to be a legitimate means of protecting democracy or, rather, limiting absolute power by making it impossible to concentrate power in one place. ${ }^{8} \mathrm{As}$ a result, the principle of the SOP is reflected in many modern constitutions, including those of the United Kingdom, the United States and France, among other countries. Therefore, it would be feasible to state that the SOP is typical of both common law and civil law systems. ${ }^{9}$

The aim of SOP, as pointed out by Montesquieu, is to "prevent the concentration of all power in the hands of a single ruler." ${ }^{10}$ Therefore, SOP in a criminal justice system is meant to prevent power abuse and ensure the protection of the vulnerable populations. ${ }^{11}$ The population that is involved in the criminal justice system is indeed particularly vulnerable and requires effective safeguards. ${ }^{2}$ However, historically,SOP in criminal matters was not only largely ignored by the researchers; ${ }^{13}$ it also proved to be difficult to maintain. ${ }^{14} \mathrm{As}$ a result, the present study intends to rectify this issue by attracting attention to criminal justice SOP and investigating related issues.

\section{The Concept of a Criminal Justice System and its Patterns}

The term criminal justice that is employed in this paper can be defined as "the formal social institution designed to respond to deviance defined as crime."15The system is typically saidto have three subsystems: "law enforcement, courts, and corrections." 16 The first one is concerned with enforcing laws, which is carried out by specific agencies through the activities related to crime: its prevention, detection, and response to it (investigation and apprehension). ${ }^{17}$ The second one consists of the courts that uphold laws by resolving disputes, ${ }^{18}$ and the third one is concerned with punitive operations, as well as

\footnotetext{
${ }^{1}$ Al-Qudsy and Rahman, supra (n 11) at 620; see also Rehman, Ibrahim and Bakar, supra (n 11) at 68.

${ }^{2}$ Rehman, Ibrahim and Bakar, supra (n 11) at 68.

3/bid. at 69 .

${ }^{4} /$ bid. at $70-71$.

$5 /$ bid. at 72 .

${ }^{6}$ Marco Goldoni, 'Montesquieu and the French Model of Separation of Powers' (2013) 4 Jurisprudence 20, 22.

7/bid. at31.

8Michael Socarras, 'Judicial Modification of Statutes: A Separation of Powers Defense of Legislative Inefficiency' (1985) 4 Yale Law \& Policy Review 228, 228-229; see alsoSamuels (n 1) 1; Conway, supra (n 2) at 306- 307.

${ }^{9}$ Murphy and Stoica, supra (n 9) at 224.

10/bid.224.

${ }_{11}^{11}$ Samuels (n 1) at 706; see also Hall, supra (n 16) at 352-353; Clark, supra (n 15) 971, 971-989.

${ }^{12 B}$ Barkow, supra (n 12) 989, 995.

13/bid. 991.

${ }^{14}$ Ashworth, supra (n 17) 578, 590; see also Barkow, supra (n 12) 989, 991.

${ }^{15}$ Lawrence Travis and Bradley Edwards, Introduction to Criminal Justice (Routledge 2014) at 3.

${ }^{16} / \mathrm{bid}$. at 20.

17 lbid. at 54.

18/bid. at 57.
} 
rehabilitation. ${ }^{1}$ Criminal justice systems are complex and vary from country to country. In the present study, the criminal justice system of Kuwait is going to be considered.

\section{Barkow's Review}

The article by Rachel E. Barkow2presents a critical analysis of the classical approach to SOP and demonstrates the fact that criminal-matters SOP has the specific features that require a different approach. According to Barkow, the typical approach to SOP which is applied to administrative law consists of a relatively flexible "blending of powers" combined with regular checking aimed at ensuring the lack of power abuse. The flexibility can provide the opportunity to step back from full, complete SOP in order to enable the "government to respond more readily to criminal matters." ${ }^{3}$ On the other hand, an alternative approach would consist of strict adherence to SOP in criminal matters to ensure the lack of power abuse which, in this context, can have disastrous consequences. In other words, Barkow views SOP as a form of possible protection of the population from power abuse, which can technically be modified (be made less strict and more flexible) as long as it is combined with another safeguard (checks in the first example).

When analysing the SOP in the US, Barkow claims that the criminal-matters SOP happens to follow the flexible approach with the exception of checks, which the author defines as insufficient, claiming that only the Constitutional rights can be considered criminal-matters safeguards in the country. ${ }^{4}$ According to the author, they are not sufficient when structural power abuse is concerned. ${ }^{5} \mathrm{As}$ a result, Barkow suggests that criminal-matters SOP is a field that needs separate, specific attention and consideration when determining its significance and potential forms, as well as safeguards. ${ }^{6}$ The author criticises the lack of attention to the topic within academic literature, offers an analysis of the SOP that she observed in the US and proposes a different approach, as well as the justification of the reasons for her suggestions.

While the specifics of the US SOP are not pertinent to the present study, the rest of the article can be viewed as the framework adopted by the current investigation. In particular, Barkow claims that SOP in criminal matters is particularly important because of the potential negative outcomes (threat to human rights) of power abuse, ${ }^{7}$ that strict SOP in criminal matters is a working mechanism for preventing power abuse because it directly prevents power from accumulating in a specific branch, ${ }^{8}$ and that this approach would be functional within the criminal matters context specifically because of the features of that context. ${ }^{9}$ Consequently, Barkow advocates for amore vigorous enforcement of SOP within the criminalmatters context. ${ }^{10}$

Barkow's investigation is based on a literature review and analysis of the Constitution of the US, as well as some cases that illustrate her points. Despite this fact, Barkow's work is of relevance to a study on Kuwait since certain similarities can be found in the development of the Kuwaiti SOP and that of other governments. For example, the process that characterises the development of the Kuwaiti SOP can be termed democratisation, which has been taking place in countries all over the world. ${ }^{11}$ Also, Barkow provides a sound argument for the idea that criminal-matters SOP is strongly connected to, and even rooted in, the Constitution, which can be used to justify the approach used by the proposed study. Similarly, works by Samuels and Al-Zumai illustrate the way the constitutions of different countries, including Kuwait, establish the SOP principle. ${ }^{12}$ Thus, Barkow's work can be regarded as a framework that guides the current research from the point of view of its content and methodology.

\footnotetext{
$1 /$ bid. at 62.

Barkow, supra (n 12) 989, 989.

3/bid. at 992.

$4 /$ bid. at 993.

5/bid.at 1031.

$6 /$ bid. at 993.

7/bid. at 1012-1013, 1028-1029.

$8 \mathrm{bid}$. at 1032-1033.

$9 /$ bid. at 996.

10/bid. at 1053.

${ }^{11}$ Stepan et al., supra (n 40) 35, 46-47.

12Samuels, supra (n 1) 1-31; see also Al-Zumai, supra (n 40) at 5.
} 


\section{The Criminal Justice System of Kuwait}

The criminal justice system of Kuwait includes the typical elements of such a system, that is, the law enforcement agencies, the courts, and the correctional institutions. ${ }^{1}$ The Kuwaiti Penal Code(Law No. 16 of 1960) contains the information pertinent to crimes and penalties, ${ }^{2}$ and the criminal procedures are guided by the Kuwait Code of Criminal Procedure (Law No. 17 of 1960). ${ }^{3}$ Overall, however, very few recent resources are available on the topic of the criminal justice system in Kuwait. For example, when researching political crimes, which is one of the SOP criteria proposed within this research, a lack of resources that would consider this phenomenon in Kuwait is apparent. The National Security Law, ${ }^{4}$ which is the Law No. 31 of 1970 (Act Amending the Provisions of the Penal Code),seems to be dedicated to this topic. Indeed, the law focuses on the crimes that can be concerned withstate security, describing them and stating the related punishments. The law has been labelled as insufficiently detailed and termed, which, according to specialists, might result in abuse. ${ }^{5}$ Mousavi described an example in which a woman's tweet was reinterpreted to imply "reproach of the Prince person,"6 which is punishable according to Article 25 of the law. ${ }^{7}$ Moreover, since the term "political crime" is not used by the document, it is difficult to determine if this category of crime is specifically acknowledged and regulated by the Kuwaiti government. Secondary sources on the topic are also rather rare, which limits the ability of this study to assess the way political crimes are handled in the country. Thus, Kuwaiti criminal system can be viewed as understudied. However, a report developed with the help of the Kuwait International Legal Research Centre and the Queen's University of Belfast has provided a short overview of the system and its issues in $2016 .{ }^{8}$

One of the first issues that the report considers consists of the fact that the criminal justice system of Kuwait does not exhibit a "principled" or "coherent" structure, which is why some important elements are missing. ${ }^{9}$ According to the report, this issue makes the strategic development of the system more difficult and hinders the process of policy formation. ${ }^{10}$ Similarly, the authors mention the lack of officials' training, insufficient guidance (code of practice) for crime investigation, and resource shortages, as wellas some more specific challenges. ${ }^{11}$ The report focuses on issues without considering the positive elements. Still, the mentioned issues are important to review in the present research since they provide the opportunity for analysing the concerns of Kuwaiti criminal justice system, which may be pertinent to the analysis of its SOP. Apart from that, the Kuwaiti government and legal and academic communities have expressed the idea that the justice system of Kuwait requires some improvement. ${ }^{12}$ Therefore, the analysis of the data from the report appears to be particularly important. The details about the elements of the Kuwaiti criminal justice system are presented below.

It is alsonoteworthy that Kuwait is a part of multiple international treaties and organisations, which have affected its criminal justice system. For example, Kuwait is a member of the Gulf Cooperation Council. ${ }^{13}$ Similarly, it is a part of the United Nations, which means that it is also a member of a variety of affiliated entities, including, for instance, the United Nations Educational, Scientific and Cultural Organization or the United Nations Development Programme, which is reported to have particular influence in the country. ${ }^{14}$ Regarding the relevant treaties, Kuwait has signed the Charter of the United Nations, ${ }^{15}$

\footnotetext{
1John Morison and Brian Grimshaw, Investigation, Process and Legal Standards within the Criminal Justice System in Kuwait (Queen's University Belfast, 2016) at 3.

2USA International Business Publications, Kuwait justice system and national police handbook (USA International Business Publications 2007) at 46.

${ }^{3}$ Kuwait, Law No. 17 of 1960: Code of Criminal Procedure, 1960, art. 1-75.

${ }^{4}$ Kuwait, Law No. 31 of 1970: Act Amending the Provisions of the Penal Code (National Security Law), 1970, art. 1-58.

5Mahmoud Rudi Mousavi, 'A Comparative Study between Kuwait and Britain Level of Understanding the Scope of Free Speech in Both Countries' (2016) 7 International Journal of Educational Research and Reviews 880, 884.

$6 /$ bid. 883-884.

${ }^{7}$ Kuwait, Law No. 31 of 1970: Act Amending the Provisions of the Penal Code (National Security Law), 1970, art. 25.

${ }^{8}$ Morison and Grimshaw, supra(n 71) at 3.

9/bid. at 7.

10/bid. at 7 .

$11 /$ bid. at 7 .

${ }^{12}$ Morison and Grimshaw, supra(n 71)at 5.

${ }^{13}$ Gulf Cooperation Council, 'Member States' (Gulf Cooperation Council, 2018), para. 6. accessed 18 March 2018.

14 United Nations, 'The UN System in Kuwait' (United Nations, 2018), para. 1. accessed 18 March 2018.

15 United Nations, 'Charter of the United Nations and Statute of the International Court of Justice' (United Nations, 2018), para. 1.

accessed 18 March 2018
} 
theKyoto Protocol, ${ }^{1}$ and the Convention against Torture ${ }^{2}$ toname just a few relevant documents. The latter convention is connected, for instance, to the National Security Law No. 31/1970, which criminalises torture. ${ }^{3}$ The legal education in Kuwait also incorporates international law courses. ${ }^{4}$ Thus, Kuwait's criminal justice system has been impacted by the international influences.

\section{Separation of Powers in Kuwait and Article 50 of the Constitution}

In Kuwait, the history of the SOP is related to the history of the country and its constitution, and it can be regarded as an example of the democratisation of a monarchy. ${ }^{5}$ Therefore, a brief history needs to be provided. Kuwait has a rich history that, among other things, involved being a centre of trade. ${ }^{6}$ In 1938, oil was discovered in the area, which spurred on the country's economic growth after the Second World War. ${ }^{7}$ This possibly facilitated the democratisation of the country, as exemplified by freedom of expression in the press, which has been greater than anywhere else in the Arab world since the previous century. ${ }^{8}$ Apart from that, the proclamation of the country's independence in 1961 was a major step towards its democratisation. ${ }^{9}$ Thus, the specifics of the country's economic and political development might have prepared it for the introduction of an increasingly independent SOP. Also, the development of education and increased awareness of political concepts has contributed to the process. ${ }^{10}$ Similarly, the integration of Western liberal attitudes into the life of the people of Kuwait must have mirrored the adoption of the SOP, which may have seemed premature at the time but appears to have been carried out smoothly. ${ }^{11}$ Here, it should be pointed out that citizenship of Kuwait is a birthright ${ }^{12}$ connected to the nationality of the father of the child. ${ }^{13}$ In other words, a child fathered by a Kuwaiti in any country is Kuwaiti; also, foundlings found in Kuwait are considered Kuwaiti. ${ }^{14}$ Furthermore, Kuwaiti citizenship can be granted for prolonged residence in the country (at least 15 consecutive years for Arab people), for various services to Kuwait, and other factors. ${ }^{15}$

According to Barkow, in the United States, "the Constitution separates legislative,executive, and judicial power to prevent tyranny and protect liberty", and this principle works for many countries, including Kuwait. ${ }^{16}$ The Constitution of Kuwait was adopted in 1962 after the country was proclaimed independent, ${ }^{17}$ and the principles of the codified law system were reflected in its articles. ${ }^{18}$ According to Hijazi, the Kuwaiti Constitution reflects and determines the approach to dividing powers in the country's criminal justice system. ${ }^{19}$ Articles 6 and 7 state that Kuwait has a democratic government and its justice system is based on the principles of democracy and equality. ${ }^{20} \mathrm{In}$ addition, Article 8 of the Constitution notes that the state guarantees the security and protection of its citizens. ${ }^{21}$

\footnotetext{
1 United Nations, 'A Kyoto Protocol to the United Nations Framework Convention on Climate Change' (United Nations, 2018), para. 1. accessed 18 March 2018

2 United Nations, 'Convention against Torture and Other Cruel, Inhuman or Degrading Treatment or Punishment' (United Nations, 2018), para. 1. accessed 18 March 2018

${ }^{3}$ Kuwait, Law No. 31 of 1970: Act Amending the Provisions of the Penal Code (National Security Law), 1970, art. 53, 56.

4Williamson, supra (n 10) 43.

5Stepan et al., supra (n 40) at 45-47; see also Salameh and Al-sharah, supra (n 40) 57, 57-58.

${ }^{6}$ Rosemarie Zahlan, The Making of the Modern Gulf States (Routledge 2016) at 24-27.

${ }^{7}$ Maria O'Shea, Michael Spilling and Marshall Cavendish, Kuwait (Routledge 2010) at 66-67; see also Michael Herb, The Wages of Oil (Cornell University Press 2014) 1-14; see also Jill Crystal, Kuwait: The Transformation of an Oil State (Routledge 2016) at 66-67.

8Michael Casey, The History of Kuwait (Greenwood Publishing Group 2007) at 70.

${ }^{9}$ Salameh and Al-sharah, supra (n 40) 57,58.

${ }^{10}$ Salameh and Al-sharah, supra (n 40) 57,59.

${ }^{11}$ Hijazi, supra (n 21) 428, 436.

${ }^{12}$ Constitution of Kuwait, 1962, art. 27-28.

${ }^{13 K u w a i t, ~ N a t i o n a l i t y ~ L a w, ~ 1959, ~ a r t . ~ 1-2 . ~}$

${ }^{14} / \mathrm{bid}$. art 3.

15/bid. art. 4-5.

${ }^{16}$ Barkow, supra (n 12) 989, 990. See Constitution of Kuwait, 1962, art. 50

${ }^{17}$ Salameh and Al-sharah, supra (n 40) 57,58.

${ }^{18} \mathrm{Hijazi}$, supra (n 21) 428, 437.

$19 /$ bid437.

${ }^{20}$ Constitution of Kuwait, 1962, art. 6, 7.

21/bid. art. 8.
} 
Article 50 of the Constitution declares the principle of the SOP for the state, which is reflected in the criminal justice system. ${ }^{1}$ Alhajeri demonstrates that the Constitution creates a threefold SOP and entrusts specific powers in its elements, whilst also requiring that they are independent of each other. In her article, Barkowalso answers the question about the role of the Constitution in determining the SOP for the criminal justice system. She states that"each branch must agree before criminal power can beexercised against an individual. Congress must criminalise the conduct, the executive must decide to prosecute, and the judiciary (judges andjuries) must convict". ${ }^{2}$ The same approach is also followed in Kuwait because Parliament criminalises the conduct, guidelines for prosecutors are written according to the Constitution, and the judiciary is responsible for convicting, employing the principles of law adopted from the French and Egyptian systems. ${ }^{3}$

An analysis of the Constitution of Kuwait reveals an important element of its articles: the figure of the Amir. The legislative power is "vested in the Amir and the National Assembly"; 4 the executive power "shall be vested in the Amir, the Cabinet and the Ministers," ${ }^{\prime 5}$ and the judicial power "shall be vested in the Courts in the Amir's name." ${ }^{\prime 6}$ Article 56 also states that Ministers are appointed by the Amir, but the number of Ministers cannot be greater than one-third of the National Assembly, which is formed through "general direct secret ballot."7 Both males and females are allowed to vote after they reach the age of $21 .{ }^{8}$ Thus, the people's will is generally expressed by the National Assembly, and the suffrage of Kuwait is considered to be "near universal" and fair. ${ }^{9}$

With respect to legislation, the Amir has the right to propose, sanction, and promulgate laws, and laws can be submitted by the National Assembly to the Amir. Also, the Amir can produce a variety of decrees that can be used to enforce laws, regulations, and "other necessary rules."10 Thus, the legislative and executive powers are closely connected to the Amir, even though his power is balanced out by the Cabinet (chosen by himself, preferably from the National Assembly) ${ }^{11}$ and the National Assembly (chosen by the people). ${ }^{12}$ The candidates must be Kuwaiti, at least thirty years old, and fluent in Arabic; also, they have to correspond to the current requirements of the Electoral Law. ${ }^{13}$ Overall, the Amir possesses great power, but the Constitution limits it notably. ${ }^{14}$

It is acknowledged that the Assembly "plays an active and substantive role in governance, both in legislating and in monitoring the government," especially when compared to the activities of parliaments in other constitutional monarchies of the region. ${ }^{15}$ In particular, the Amir's decrees and the appointment of the Prime Minister can be controlled by the body to an extent. ${ }^{16}$ More than that, in 2006 the National Assembly set forward the appointment of Amir Sheikh Sabah Al-Ahmad Al-Sabah, instead of the then-ailing Amir Sheikh Sa'ed Al-Abdulah Al-Sabah. This was considered an empowering step that signified a strengthening of democratic tendencies in Kuwait. ${ }^{17}$ As a result, through the Assembly, the people became

\footnotetext{
'MashaelAlhajeri, 'Judiciary and the Administration of Justice in Building and Construction Disputes Under Kuwaiti Law' (2008) 22 Arab Law Quarterly 199, 199-200.

2Barkow, supra (n 12) 989, 1017; see also John Manning, 'Separation of Powers as Ordinary Interpretation' (2011) 2Harvard Law Review 1939, 1945.

${ }^{3}$ Abdul Reda, 'A Summary of the Legal and Judicial System in the State of Kuwait' (1991) 6Arab Law Quarterly 267, 270.

${ }^{4}$ Constitution of Kuwait, 1962, art. 51.

5/bid. art. 52.

$6 /$ bid. art. 53.

${ }^{7} / \mathrm{bid}$. art. $56,80$.

${ }^{8}$ Freedom House, 'Kuwait' (Freedom House, 2016), para. 3. accessed 12 January 2017

${ }^{9}$ Stepan et al., supra ( $\left.\mathrm{n} 40\right)$ at 45.

${ }^{10}$ Constitution of Kuwait, 1962, art. 71-73.

${ }^{11}$ Constitution of Kuwait, 1962, art. 56.

12/bid. art. 80.

13/bid. art. 82.

${ }^{14}$ Salameh and Al-sharah, supra (n 40) 57,65 .

${ }^{15} \mathrm{Al}-Z$ umai, supra ( $\left.\mathrm{n} 40\right)$ at 2.

16 Freedom House, supra (n 114) para. 3.

${ }^{17}$ Al-Zumai, supra (n 40) at 3; see also KjetilSelvik and Ghanim Alnajjar, 'Kuwait: The Politics Of Crisis' in KjetilSelvik and Bjørn Olav Utvik (eds), Oil States in the New Middle East: Uprisings and stability (Routledge 2015) at 100.
} 
the source of sovereignty for the country. ${ }^{1}$ According to Selvik and Alnajjar, the people of Kuwait can be characterised as politically active, ${ }^{2}$ which appears to correspond to reality, despite the relatively subjective character of the term.

The Kuwaiti judiciary is supposed to be completely separated from the Amir, since "no Authority may wield any dominion over a Judge."3But the judges are expected to perform their duties in the name of the Amir. Also, it is apparent that a country's judicial system is unlikely to be completely immune to varied external forces. ${ }^{4}$ Still, it can be stated that the Constitution of Kuwait postulates and demands the independence of the system from the direct influence of external forces, including the executive power. ${ }^{5}$

However, certain boundaries and obstacles to the continued development of Kuwaiti democracy have been identified, including political challenges (for example, power imbalances and a lack of unity in the opposition) and economic issues the liberalisation of the economy is considered unfinished, ${ }^{6}$ which means that the government is not ready to relinquish its control over a number of economic aspects, for example, lending rate ceilings. ${ }^{7}$ As shown by Al-Zumai, both economic and political issues tend to weaken the development of democracy, including the empowerment of Kuwaiti parliament and voters, ${ }^{8}$ which eventually hinders effective SOP. It has been established that the Amir still holds impressive power, which is enhanced by the extensive involvement of the country's princes in political matters as Ministers. ${ }^{9}$ Also, a number of setbacks before 1992 involved unconstitutional dissolutions of the Assembly. ${ }^{10}$ Fortunately, the new century has seen only constitutional dissolutions. ${ }^{11} \mathrm{As}$ a result, the democratisation of the country is incomplete.

The analysis of key governmental bodies also indicates that majoritarianism appears to be present in the Kuwaiti political system. Majoritarianism can be defined as an approach to politics that favours a particular majority, resulting in that majority being able to influence a country's politics to a greater extent. ${ }^{12}$ Given the fact that judges are not immune to these influences, majoritarianism is clearly an issue for SOP in criminal law. This is especially true for Egyptian judges in Kuwait, who are particularly unwilling to disturb the powerful groups of the country because the salary of a judge is greater in Kuwait than in Egypt. ${ }^{13}$ As pointed out by Ashworth and Horder, the "individuals whose preferences are at odds with those of the majority" are bound to "lose out" in the case of democratic or participatory decision-making. ${ }^{14}$ Thus, the main problem with majoritarianism is the neglect of minorities, which attracts criticism and calls for an approach that is more representative..$^{15}$ It is noteworthy that offenders are a minority, and from the perspective of the criticism of majoritarianism, a balance between the protection of the majority and the human rights of both groups needs to be found. ${ }^{16}$ In general, majoritarianism is relatively typical for Asian countries, and Kuwait does not appear to be an exception. ${ }^{17}$

To sum up, the existing state of affairs in Kuwait cannot be regarded as an illustration of the theoretically ideal SOP, even though it has travelled a long way from the archetypical monarchy. ${ }^{18}$ Nowadays, liberal tendencies in Kuwait remain strong ${ }^{19}$

'Fadi Nader, 'Kuwait: Human Rights Under the Constitution' (2000) 7 YB Islamic \& Middle EL 267, 267.

2Selvik and Alnajjar, supra (n 123) at 98.

${ }^{3}$ Constitution of Kuwait, 1962, art. 163.

${ }^{4}$ Hall, supra (n 16) at 364.

${ }^{5}$ Alkarama Foundation, supra (n 26) at 12.

${ }^{6}$ Al-Zumai, supra ( $\mathrm{n} 40$ ) at 1, 3.

7 International Monetary Fund, Kuwait: Selected Issues and Statistical Appendix (International Monetary Fund 2012) at 51.

${ }^{8}$ Al-Zumai, supra ( $\mathrm{n} 40$ ) at $1,3$.

9Stepan et al., supra (n 40) 35, 46-47.

10 Al-Zumai, supra (n 40) at 5; see also Salameh and Al-sharah, supra (n 40) 57, 66.

11 Al-Zumai, supra (n 40) at 2.

12Petra Schleiter and Valerie Belu, 'The Decline of Majoritarianism in the UK and the Fixed-term Parliaments Act' (2016) 69

Parliamentary Affairs 36, 36-38.

${ }^{13}$ Brown, supra (n 22) at 159-160.

${ }^{14}$ Andrew Ashworth and Jeremy Horder, Principles of Criminal Law (OUP 2013), 26.

15Matthew Hall and Joseph Ura, 'Judicial Majoritarianism' (2015) 77 The Journal of Politics 818, 823.

${ }^{16}$ Andrew Ashworth, Lucia Zedner and Patrick Tomlin, Prevention and the Limits of the Criminal Law (OUP Oxford 2013 ), 89.

${ }_{17}^{17}$ marDajani, 'The Middle East's Majority Problems: Minoritarian Regimes and the Threat of Democracy' (2015) 38 Ethnic and Racial Studies 2516, 2527.

18 Kristian Ulrichsen, 'Politics and Opposition in Kuwait: Continuity and Change' (2014) 4Journal of Arabian Studies 214, $214-217$.

19 Meir Hatina and Christoph Schumann, Arab Liberal Thought after 1967 (Springer 2015) at 4-8, 102-103 
despite the difficulties in establishing them ${ }^{1}$ and the fact that the United Nations insist on the further development of democratic governance in the country, ${ }^{2}$ which is its policy in the Asian region in general. ${ }^{3}$ Kuwait seems to respond favourably to such comments as it tends to highlight the importance of freedoms ${ }^{4}$ and equality 5 for its population, while also emphasising its agreement with the UN. ${ }^{6}$

It is important to note that, according to Conway, no currently existing system has managed to achieve the pure threefold SOP that, according to the author, exists only theoretically, ${ }^{7}$ and this results in both risks and benefits for citizens. Similarly, Daughterly points out that separating the judicial branch from the executive one is a necessity, but one that is not always possible, providing an example of a politically-influenced case of criminal prosecution. ${ }^{8}$ Therefore, the issues that are experienced by Kuwait do not indicate the impossibility of change and, in fact, signify a room for improvement.

\section{The Past Influence of British Jurisdiction and the Continuing Impact of French, Egyptian, and Islamic Law on the Criminal Justice System of Kuwait in Terms of Separation of Powers}

The current criminal justice system of Kuwait is based on contrasting principles of British Jurisdiction(as a past influence) as well as French, Egyptian and Islamic law (that can be described as continuing influences). This feature makes the criminal justice system in Kuwait rather unique in its diffusion and dependence on several different patterns, including the reference to civil codes and Islamic views. ${ }^{9}$ Farran, Gallen, and Rautenbach ${ }^{10}$ offer a collection of chapters that are devoted to different cases of law diffusion. One of them isWilliamson's work, ${ }^{11}$ which refers to Kuwait and considers the way that a variety of legal concepts are diffused within its legal system. The author also points out that scholars do not tend to have a unanimous opinion concerning the classification of the Kuwaiti legal system, which is common for the subject ${ }^{12}$ but which results in very different appraisals of the share and influence of different sources of Kuwaiti law. The author mentions that some scholars, for example, Palmer, choose to highlight civil and Islamic law while, for example, the Central Intelligence Agency, which also devotes reports to the topic, emphasises common and French civil law. ${ }^{13}$ According to Williamson, the country's history (in particular since colonisation and the restoration of independence) is responsible for the process of diffusion, and this process may explain "the discrepancies between these classifications." ${ }^{4}$ The present section will consider all the pertinent influences that have had a major impact on Kuwaiti law.

\section{British Jurisdiction (Past Influence)}

Kuwait used to be under the influence of the British Jurisdictionsince 1925and until the country became independent in 1961. ${ }^{15}$ Technically, however, Kuwait was not colonised by Great Britain; instead, the two countries entered an AngloKuwaiti Treaty, in which it was specified that Great Britain would provide protection but would not interfere with the internal

\footnotetext{
1 Brown, supra (n 22) at 158.

2 Executive Board of the United Nations Development Programme, the United Nations Population Fund and the United Nations Office for Project Services, 'Draft Country Programme Document for the State of Kuwait (2015-2017)' (United Nations, 2014) at 23 accessed 18 January 2017

3Saikal A, 'Authoritarianism, Revolution and Democracy: Egypt and Beyond' (2011) 65 Australian Journal of International Affairs 530544. See also, UNDEF, 'Doers of Democracy - Asia \& Pacific' (UNDEF, n.d.) accessed 17 February 2017

${ }^{4}$ His Highness Sheikh Naser Al-Mohammad Al-Ahmad Al-Sabah, Prime Minister, 'Statement Before The Sixty-Fifth Regular Session Of The United Nations General Assembly' (United Nations, 2010) at 3 accessed 12 February 2017.

5/bid. 2.

6/bid. 1.

${ }^{7}$ Conway, supra (n 2) at 322.

8 Donald Daugherty, 'Separation of Powers and Abuses in Prosecutorial Discretion' (1988) 79 Journal of Criminal Law and Criminology $953,994$.

'Liebesny, supra (n 22) 110.

${ }^{10}$ Sue Farran, James Gallen, and Christa Rautenbach, The Diffusion of Law: The Movement of Laws and Norms around the World (Routledge 2016), 1-235.

11Williamson, supra (n 10) 25-41

12/bid. at 41. More discussion in the subject see EsinÖrücü, 'What is a Mixed Legal System: Exclusion or Expansion' (2008) 12

Electronic Journal of Comparative Law1, 3.

13Williamson, supra (n 10)34. See aslo V.V. Palmer, 'Mixed legal system' in Bussani and Matei (eds), The Cambridge Companion to Comparative Law (Oxford University Press, 2012) at 381.

14Williamson, supra (n 10)34-35

15/bid. 27-28.
} 
affairs of Kuwait. ${ }^{1}$ Great Britain had entered such treaties with multiple other countries, including, for example, Bahrain. ${ }^{2}$ The treaties affected the external politics of the Gulf states, ${ }^{3}$ but they were intended to have no consequences for their internal affairs, including positive ones. ${ }^{4}$ It is noteworthy that the level of democracy in Bahrain ${ }^{5}$ is considered to be lower than that in Kuwait. ${ }^{6}$ For instance, in both countries, there is a constitution, a king (Bahrain) or Amir (Kuwait), a cabinet of ministers appointed by the king or Amir, and a National Assembly elected by the people. However, in Bahrain, the ministers constitutehalf of the government, ${ }^{7}$ and in Kuwait, ministers can only take up one-third of it, ${ }^{8}$ providing more power for the representatives of the people. Thus, the two countries that share similar history have moved in the same direction (towards complete independence and democracy), but Kuwait has moved further. It has been suggested that the activities of colonising countries could have beeneither beneficial or harmfulfor the development of democracy in a country. ${ }^{9}$ Possibly, the lack of direct colonisation and the presence of only treaties reduced the potential negative impacts of outside influence on Kuwaiti democratic growth.

Thus, in Kuwait, the British Jurisdiction operated separately from the National one. In other words, between 1925 and 1961 , the country had two separate and very different Jurisdictions,$^{10}$ the latter of which applied to predominantly to Kuwaiti citizens while the former was applicable to other groups, mostly British, Americans, Greeks, and some others. ${ }^{11}$ According to the literature of the time, the National Jurisdiction was " relativelysemitribal"12and had "no written laws, no procedure and no defined courts"13 with the exception of the "personal status matters, which were and stillare governed by Islamic law."14 The British Jurisdictionwas based on English legal principles and mirrored the procedures and court functions of England. ${ }^{15}$

The two Jurisdictions worked together for mixed cases, but in general, the existence of two different jurisdictions led to problems and confusion. ${ }^{16} \mathrm{Given}$ the advantages of a system with written laws and defined procedures, the British Jurisdiction became popular in Kuwait, but consequently, it was also attacked by the nationalists because it was symbolic of potentially colonialist issues. ${ }^{17}$ Again, Kuwait was not a colony; it was a party in a treaty with Great Britain, but at the time, the presence of the British Jurisdiction in Kuwait caused unease, especially among the nationalists. ${ }^{18} \mathrm{As}$ a result, in 1959 , it was established that the British Jurisdiction in Kuwait would be repealed after a new working system would have been implemented, ${ }^{19}$ and in 1961, the British Parliament officially fulfilled that promise. ${ }^{20}$

The British Jurisprudence legacy is multidimensional. According to Professor Abdullah Alnafisi, who is a former Parliament member of Kuwait, the influence of British specialists like John Richmond, George Middleton, Edward Heath, and William Loose illustrates that legacy. In particular, the named figures promptedthe Amir to pursue democratic principles and freedom of the press. ${ }^{21}$ On the other hand, there have been cases in which Britain hindered the development of SOP and

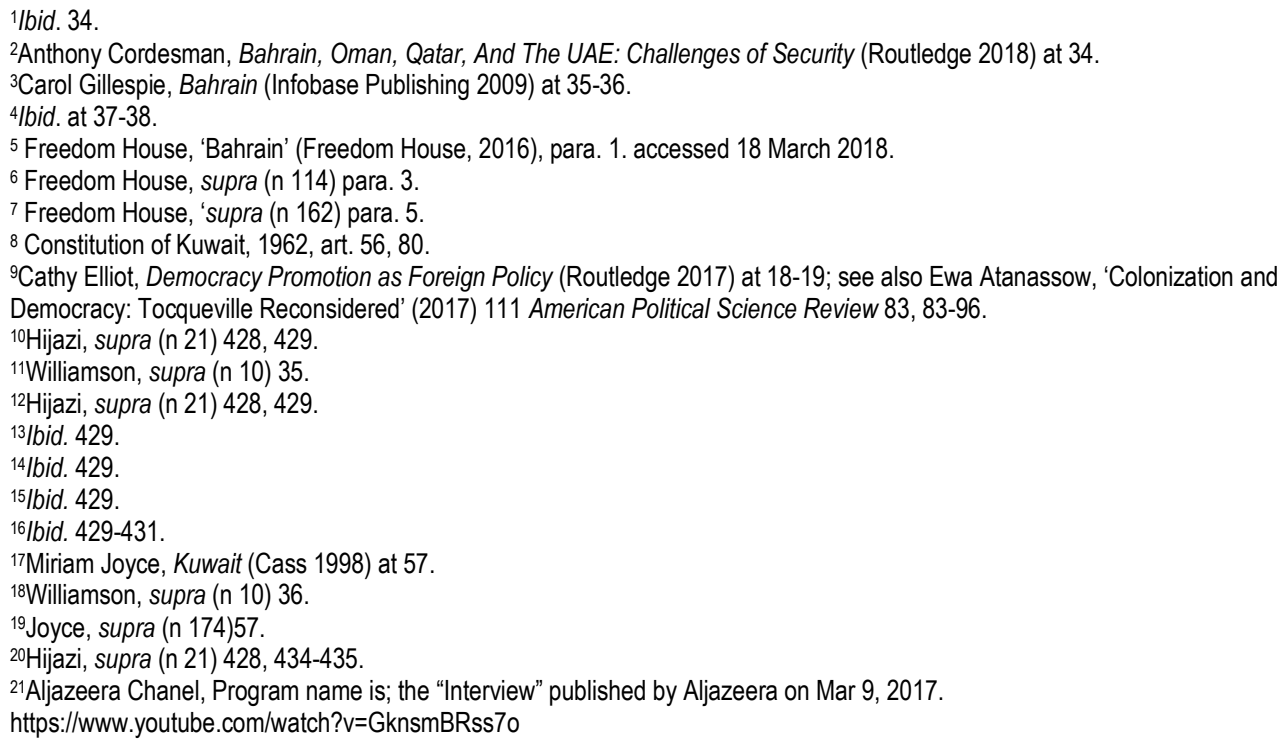


democracy, for example, by ensuring the dissolution of the first Shura Council in Kuwait. ${ }^{1}$ The Jurisdiction that was developed for Kuwait in the years following the decision to repeal British Jurisdiction was not based on the principles of the latter, which limits its impact on Kuwaiti legislation. However, it can be argued that the reason for choosing non-British legislation for Kuwaiti laws might be connected to colonialism and subsequent rejection of British Jurisdiction. ${ }^{2}$ Thus, the choice of non-British legislation for Kuwait may have been the result of its presence in the country, which demonstrates that British Jurisdiction is an important influence on Kuwaiti laws.

\section{French Civil Law in Kuwait (Latin Civil Law)}

The French law has served as an inspiration for the codified law of Kuwait in the majority of areas that do not cover personal status or financial matters (in particular, banking and tax legislation), which are governed by Islamic law. ${ }^{3}$ This outcome was achieved indirectly: the legal system of Kuwait that was developed to supplant the British system was based on the Egyptian law,and the latter is noticeably inspired by the French law. ${ }^{4}$ Other influences have also been noted; for example, the Kuwaiti Law of Commerce was created with the help of Iraqi law, which is also based on French legal principles. ${ }^{5} \mathrm{In}$ turn, a major source of the French law is the Roman law, which is associated with the prioritisation of functional codification. ${ }^{6}$ Thus, the French law has influenced the Kuwaiti law indirectly through multiple sources while also bringing its own sources to have an impact as well.

According to Williamson, French law tends to be viewed as relatively less flexible and convenient than the British law. For example, the author notescertain French law-relateddrawbacks that can affect economic development. In particular, the British law is considered to be more business-friendly (providing "more adequate institutions for financial markets") and implies less governmental interventions than the French law. ${ }^{7}$ Williamson amends that this idea is supported by limited evidence and can be contested, but the author also suggests that the Kuwaiti legal systemmight have inherited the issues related to the French law. ${ }^{8}$ The author exemplifies this statement usingthe comments of the Oxford Business Group regarding the restrictive legislationin Kuwait that may result in challenges for the economic development of the country.

Admittedly, the report mentions some information about restrictive legislation, for example, that pertinent to insurance. ${ }^{9}$ However, it also highlights some achievements in the field, including the movement of the tax legislation towards a more liberal one. ${ }^{10}$ Therefore, it is difficult to assess the impact of French law on Kuwaiti legislation, but it is clearly present.

\section{Egyptian Law and the Kuwaiti Civil Code Used by Judges}

The Egyptian law was particularly important for the development of the Kuwaiti legislation because the working system that was meant to supplant the British Jurisdictions in Kuwait was based on it. Indeed, Dr Abdel-Razzaq al-Sanhouri (a famous and accomplished ${ }^{11}$ specialistfrom Egypt)was invited to develop the new Kuwaiti legislation, and since he was Egyptian, he used the Egyptian legal system for inspiration. ${ }^{12}$

Thus, the Egyptian Law assisted in the development of the codified Kuwaiti law in the non-personal status matters along with the French Law. ${ }^{13}$ The Kuwaiti Civil Code was enacted in 1980. ${ }^{14}$ It incorporates the general rules of Kuwaiti law; the

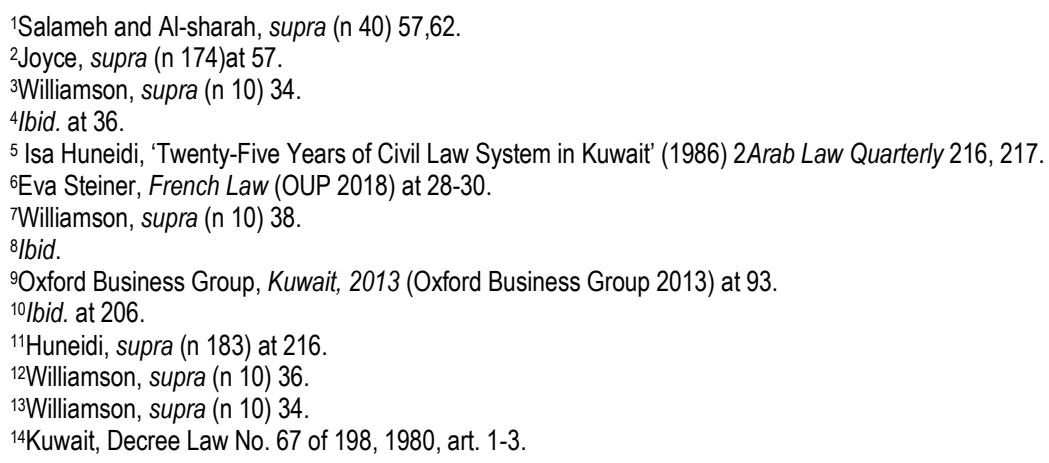


more specific cases (for example, commercial transactions) are regulated by specific laws (for example, Commercial Code). ${ }^{1}$

The new system developed by $\mathrm{Dr}$ al-Sanhouri was based on non-Kuwaiti legislation rather heavily and was also implemented in a very short time, ${ }^{2}$ which is why it was not assimilated easily and is sometimes described as unnecessarily complicated and cumbersome, as well as inflexible. ${ }^{3}$ Williamson suggests that such a conclusion is largely warranted and uses the example of the ease of conducting business in the country to demonstrate that the process is more complicated in Kuwait than in New Zealand. ${ }^{4}$ The lack of judges and lawyers in Kuwait was resolved by attracting Egyptian specialists, which is a decision that must have been necessary at the time, but which also required a different long-term solution. ${ }^{5}$ In summary, the development of the new system was not very smooth, and some of the issues related to it have remained topical to this day.

\section{Muslim Jurisprudence in Kuwait}

As mentioned, the Islamic law(Shari'a) dominated Kuwait until the middle the previous century. ${ }^{6}$ In fact, in the 1930s, the people of Kuwait petitioned for the introduction of a Shari'a-based political system. ${ }^{7}$ The influence of the Muslim jurisprudence onmodern Kuwait is notable; 8 in fact, it is explicitly stated in Article 2 of Constitution that the Islamic Shari'a is supposed to be a primary source of Kuwaiti legislation. ${ }^{9}$ However, according to Williamson, Islamic Shari'ais a major but not the main source of Kuwaiti legislation; the author points out that it is used predominantly for personal-status matters and financial services (Islamic banking is very well-developed in the country). ${ }^{10}$ In the end, the result of the law diffusion in Kuwait is a combination of Muslim law and French-Egyptian-based civil law. ${ }^{11}$ In summary, the diffusion of law in Kuwait is the result of its history, the investigation of which can help to pinpoint and comprehend some of the challenges faced by the system nowadays.

\section{The Kuwaiti Constitution as the Guarantor of Democracy and Citizens' Equality before the Law}

The Kuwaiti Constitution is the guarantor of democracy in the country, which can be provenwith the help of Article 6, which states that the country's governmental system is democratic. ${ }^{12}$ The rights of the population of Kuwait are proclaimed by Articles 27-46, which includes rights to privacy, ${ }^{13}$ freedom,,${ }^{14}$ trade unions, ${ }^{15}$ freedom of religion, ${ }^{16}$ expression, ${ }^{17}$ opinion and press ${ }^{18}$ and so on.Also, the freedom from torture and the principle of no "punishment without law" are included in the Constitution. ${ }^{19} \mathrm{Apart}$ from that, the citizen's equality is directly stated in the Constitution's preamble and supported by Article $8,{ }^{20}$ which is concerned with equal opportunities, and Article $29,{ }^{21}$ which specifically points out the equality of the people of

\footnotetext{
${ }^{2}$ Hijazi, supra (n 21) 428, 434.

3Williamson, supra (n 10) 36, 39.

4Williamson, supra (n 10) 36-37.

${ }^{5}$ Hijazi, supra (n 21) 428, 434. 138-139.

7/bid. 140.

8Williamson, supra (n 10) 25-41.

${ }^{9}$ Constitution of Kuwait, 1962, art. 2.

10Williamson, supra (n 10) 34.

11Williamson, supra (n 10) 34.

${ }^{12}$ Constitution of Kuwait, 1962, art. 6.

${ }^{13}$ Constitution of Kuwait, 1962, art. 36.

${ }^{14}$ Constitution of Kuwait, 1962, art. 42.

${ }^{15}$ Constitution of Kuwait, 1962, art. 43.

${ }^{16}$ Constitution of Kuwait, 1962, art. 35.

${ }^{17}$ Constitution of Kuwait, 1962, art. 36.

${ }^{18}$ Constitution of Kuwait, 1962, art. 37.

${ }^{19}$ Constitution of Kuwait, 1962, art. 32.

${ }^{20}$ Constitution of Kuwait, 1962, art. 8.

${ }^{21}$ Constitution of Kuwait, 1962, art. 29.
}

1USA International Business Publications, supra (n 72)at 44.

6Mohammad Al-Moqatei, 'Introducing Islamic Law in the Arab Gulf States: A Case Study of Kuwait' (1989) 4Arab Law Quarterly 138, 
Kuwait "in the eyes of the Law." In summary, the Kuwaiti Constitution guarantees human rights, democracy, and citizen equality.

\section{The Three Divisions of the Criminal Justice System in Kuwait}

\section{The Police as the Law Enforcement Body and Divisions within the Ministry of Interior}

Within the Ministry of Interior, which is responsible for enforcing the law, the Directorate of Police and Public Security ${ }^{1}$ represents the law enforcement body. ${ }^{2}$ Its divisions include those working with criminal investigation, civil defence, traffic, immigration, and so on, which corresponds to the typical activities performed by a law enforcement agency. ${ }^{3}$

There are some issues related to Kuwaiti police that can be found in literature. The recent report on Kuwaiti criminal justice suggests that there is no effective SOP with respect to investigative power when police and prosecutors are concerned. ${ }^{4}$ Apart from that, the Ministry of Interior demonstrates a lack of control over the national police, its sub-divisions, and the National Guard in relation to investigations and guaranteeing public security. ${ }^{5}$ This is the result of the existence of a rather complicated net of agencies that are responsible for internal security, which results in their responsibilities overlapping. ${ }^{6}$ Consequently, citizens' rights can be violated when individuals are unfairly imprisoned or held in police offices for more than four days without prosecution. The criminal justice system must respect human rights and freedoms, ${ }^{7}$ but the inefficiency of the system can pose a threat to them.

Naturally, the Penal Code of Kuwait contains Article 184, which states that imprisoning or arresting a person "without observing the procedures" must be punished. ${ }^{8}$ Moreover, the Constitution also contains Article 31 , which establishes that people cannot be "arrested, detained, searched, or compelled to reside in a specified place" unlawfully. ${ }^{9}$ Finally, the Prison Regulation Act 26/1962 establishes the need for a legal authorisation for imprisonment. ${ }^{10} T h u s$, there are multiple legal safeguards, but they might not be entirely successful in achieving the desired level of protection of human rights.

\section{Prosecutors as Part of the Criminal Justice System and Details of the Prosecutorial Process}

Prosecutors are a part of the judicial system of Kuwait, appearing in the courts of different levels. ${ }^{11}$ Public Prosecution ${ }^{12}$ members defend the interests of the community of Kuwait. ${ }^{13}$ The decision regarding the appointment of the candidates is made by a body called the Supreme Judicial Council. ${ }^{14}$ The latter is comprised of the Heads and Deputies of Kuwaiti Courts (including Court of Cassation, Court of First Instance, Court of Appeal, and Supreme Court of Appeal), as well as the Public Prosecutor. ${ }^{15} \mathrm{~A}$ representative of the Ministry of Justice is also present in the Council, but they are prohibited from voting. ${ }^{16}$ The activities of the Council are governed by the law. ${ }^{17}$ The appointment decision is carried out by the Minister of Justice through decrees. ${ }^{18}$ Thus, since the decision is made by the Council, which consists of the representatives of the judiciary, it can be suggested that the appointment of prosecutors does not depend on the Minister.

\footnotetext{
${ }^{1}$ Anita Burdett, Records of Kuwait (Archive Editions 2003) at 394.

${ }^{3}$ Travis and Edwards, supra(n 55)at 54.

4Morison and Grimshaw, supra(n 71)at 7.

${ }^{5}$ Crystal, supra (n 215) 469, 471.

6/bid. 474. Criminal Justice (Sweet \& Maxwell 2012), 1-5.

${ }^{8}$ Kuwait, Penal Code 16/1960 (as amended), article 184.

${ }^{9}$ Constitution of Kuwait, 1962, art. 31.

10 Kuwait, Prison Regulation Act 26/1962, art. 17-18.

${ }^{11}$ Travis and Edwards, supra(n 55)at 60.

${ }^{12}$ Constitution of Kuwait, 1962, art. 167.

${ }^{13}$ USA International Business Publications, supra (n 72)at 31-32.

${ }^{14 K}$ Kuwait, Decree Law No. 67 of 198, 1980, art. 61.

15USA International Business Publications, supra (n 72)at 32.

${ }^{16}$ Alkarama Foundation, supra (n 26) at 12.

${ }^{17}$ Constitution of Kuwait, 1962, art. 164.

${ }^{18 K u w a i t, ~ D e c r e e ~ L a w ~ N o . ~} 67$ of 198, 1980, art. 61.
}

2Jill Crystal, 'Criminal Justice in the Middle East' (2001) 29 Journal of Criminal Justice 469, 471.

${ }^{7}$ Ashworth and Horder, supra (n 137) at 48; see also Ben Emmerson, Andrew Ashworth and Alison Macdonald, Human Rights and 
Liability to prosecution is governed by the Kuwait Penal Code. ${ }^{1}$ According to a recent report, the prosecutors that were interviewed for it "appeared not to fully understand their role during the trial process."2 Apart from that, the problem of insufficient SOP between police and prosecutors seems to be problematic. ${ }^{3}$ Thus, the literature on the topic identifies some pertinent procedures and issues, but in general, Kuwaiti prosecution does not receive sufficient coverage in modern research. As a result, no reliable source was found that would critique the details of the prosecution processes in Kuwait.

\section{The Kuwaiti Judicial System and the Responsibilities of Judges}

The Judicial system of Kuwait consists of the Courts of First Instance, the Courts of Appeal, the Supreme Court or Court of Cassation, and the Constitutional Court. ${ }^{4}$ The courts of the first two degrees are comprised of three judges, and the Supreme courtconsists of the court's heads, deputies, and Consultants. The Constitutional Court is comprised of five Consultants. ${ }^{5}$ The first- and second-degree courts and the Supreme Court also incorporate multiple circuits dedicated to particular law branches. ${ }^{6}$ The Constitution points out that the Military courts are "restricted to deal with military offenses committed by members of the Armed and Public Security Forces within the limits prescribed by Law."7

According to the recent report, the judicial supervision is crucial for Kuwaiti criminal justice, but no direct guidelines on this process exist. $^{8}$

The independence of the judiciary is established Articles 50,53, and 163 of the Constitution. The Kuwaiti judiciary is supposed to be completely separated from the Amir, since "no Authority may wield any dominion over a Judge." ${ }^{B}$ But the judges are expected to perform their duties in the name of the Amir. Also, it is apparent that a country's judicial system is unlikely to be completely immune to varied external forces. ${ }^{10} \mathrm{Still}$, it can be stated that the Constitution of Kuwait postulates and demands the independence of the system from the direct influence of external forces, including the executive power. ${ }^{11}$

Theeffectiveness of Articles may be undermined by the fact that senior judicial officials are appointed by the Minister of Justice (who belongs to the administrative branch of power) through decrees. ${ }^{12}$ However, the Minister has to consult the Supreme Judicial Council before the appointment, ${ }^{13}$ and the decision should belong to the Supreme Judicial Council, ${ }^{14}$ which is comprised predominantly of the representatives of the judicial branch of power. ${ }^{15}$ The rest of the officials are appointed by the Supreme Judicial Council. However, as pointed out by Brown, the Council includes the mentioned senior officials and is not independent in its funding. ${ }^{16}$ Moreover, foreign judges are appointed after requests by the Ministry of Justice, without any discussions with the Council. ${ }^{17}$ Apart from that, the Minister is lawfully vested with the power to supervise the judiciary system. ${ }^{18}$ Thus, certain aspects of judiciary-related procedures appear to undermine the independence of the judiciary.

Some of the historical developments in the field of judicial independence can be regarded as adversely affecting the SOP. There was a notable attempt to make the justice system less dependent in the 1980s, which was curbed as a result of the suspension of Parliament in 1986 and reintroduced in the 1990s in the form of new proposals. ${ }^{19}$ In particular, the 1990s saw

\footnotetext{
1USA International Business Publications, supra (n 72)at 46.

2Morison and Grimshaw, supra(n 71)at 7.

3/bid.

4 USA International Business Publications, supra (n 72)at 31.

${ }^{5}$ Kuwait, Law No. 14 of 1973, 1973, art. 1.

6 USA International Business Publications, supra (n 72)at 31.

${ }^{7}$ Constitution of Kuwait, 1962, art. 168.

8Morison and Grimshaw, supra(n 71)at 7.

${ }^{9}$ Constitution of Kuwait, 1962, art. 163.

10 Hall, supra ( $\mathrm{n}$ 51) at 364.

${ }^{11}$ Alkarama Foundation, supra (n 26) at 12.

12USA International Business Publications, supra (n 72)at 32.

${ }^{13}$ Alkarama Foundation, supra (n 26) at 12.

${ }^{14}$ Kuwait, Decree Law No. 67 of 198, 1980, art. 61.

15USA International Business Publications, supra (n 72)at 32.

${ }^{16}$ Brown, supra (n 22) at 158.

${ }^{17}$ Alkarama Foundation, supra (n 26) at 13.

${ }^{18}$ Kuwait, Decree 23/1990, article 35, 1990.

19 Brown, supra (n 22) at 158-159.
} 
a decree limiting the independence of the judiciary; ${ }^{1}$ it prevented the Courts from considering acts of sovereignty. ${ }^{2}$ The decree was not repealed to this day. Thus, there is a need for continuous development of SOP to ensure the independence of Kuwaiti judges.

Other issues pertinent to the judges of Kuwait may also pose a threat to human rights. They may include transparency issues. ${ }^{3}$ Moreover, although judgements are usually declared to be in line with the principle of equality of all citizens before the law, they tend to take a lot of time to "move their way through the court system," ${ }^{4}$ which implies the existence of red tape.

According toLiebesny, challenges in the Kuwaiti legal system "arose initially since the courts, staffed by lawyers from Arab countries whose systems had been modernised many years ago, were not familiar with the background of the Kuwaiti system," and moreover, "the Kuwaiti court clerks and police officers on their part found the precipitous introduction of a largely alien system hard to cope with." Williamsonalso agrees that "the strong presence of foreign (mainly Egyptian) judges working in the Kuwait judiciary" creates a challenge for the system. ${ }^{6}$ The fact that judges in Kuwait are often non-citizens can undermine a sense of their legitimacy when they need to be regarded as the highest authority in determining punishments. Brown points out that the need for foreign judges is typical for some Arab countries due to their shorter legal history, which may result in less-established law schools. ${ }^{7} \mathrm{He}$ emphasises, however, that Kuwait's legal history is sufficient to avoid employing foreign lawyers and that Egyptian lawyers can only take overseas contracts (through which they are recruited in Kuwait) for a limited number of years, which, in his view, makes the problem less acute but still present. ${ }^{8}$ Currently, Egyptian judges are appointed for four years (with a possible two-year extension) through an Egypt-approved request from the Kuwaiti Ministry of Justice; as of 2011, there were 300 Egyptian judges working in Kuwait. ${ }^{9}$ The appointment of foreign judges would be expected to reduce the issue of the elitism of the judiciary, but it should be pointed out that Kuwaiti judges hold their posts for a lifetime, even though they can be removed from this position in the case of misconduct. ${ }^{10}$ Thus, it can be suggested that Kuwait suffers "from unnecessarily complicated, inflexible and sometimes outdated laws and procedures, not to mention frustrating bureaucracy." ${ }^{11}$ As a result, the authority of the courts becomes questionable. In this context, there is the possibility of the introduction of the jury system in Kuwait to increase the potential for fair trials, but researchers state that the criminal justice system of the state is not prepared for this pattern. ${ }^{12}$

It should be pointed out that the judicial independence and transparency appear to be commonly challenging to achieve, while corruption is difficult to avoid in a variety of countries, indicating that the problems are not unique to Kuwait and its SOP. ${ }^{13}$ For example, Ashworth considers the topic of the separation of powers and responsibilities in the field of restorative justice, highlighting the role of government in ensuring the independence of justice, and pointing out that state-led justice tends to have flaws and can result in failures. ${ }^{14} \mathrm{In}$ particular, Ashworth states that "the list of failures of state justice is a lengthy one." ${ }^{15}$ Still, Brown asserts that since the 1990s the process of increasing judicial independence in Kuwait has been

\footnotetext{
1 Brown, supra (n 22) at 159. See Kuwait, Decree 23/1990, art. 32 and 35, 1990.

2Kuwait, Decree Law No. 23 of 1990: Regulation of the Judiciary Law, 1990, art. 2.

3Williamson, supra (n 10) at 36.

${ }^{4}$ /bid.

5Liebesny, supra (n 22) at 110.

6Williamson, supra (n 10) at 36

${ }^{7}$ Brown, supra (n 22) at 159-160.

8 bid. 160.

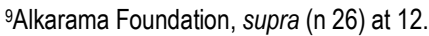

10/bid. 12-13.

${ }^{11}$ Williamson, supra $(\mathrm{n} 10)$ at 36.

12/bid 54.

${ }^{13}$ Stephan Rosiny, 'Power Sharing in Syria: Lessons from Lebanon's Taif Experience' (2013) 20 Middle East Policy 41, 43; see also Ashworth, supra (n 17) 590-592; see also Omar Azfar and William Robert Nelson, 'Transparency, Wages, and the Separation of Powers: An Experimental Analysis of Corruption' (2007) 130 Public Choice 471, 471-490.

${ }^{14}$ Ashworth, supra (n 17) 578-579, 595.

15/bid. at 590 .
} 
in motion. ${ }^{1}$ This process illustrates the fact that the government tends to develop and evolve together with the evolution of the SOP. ${ }^{2}$

\section{Resources Available for the System's Functioning}

The criminal justice system requires resources for functioning just like any other system. In particular, funding, human resources, equipment (for instance, police cars or computers) are necessary. ${ }^{3}$ However, according to the recent report on Kuwaiti criminal justice system, resources in it are not distributed adequately. ${ }^{4}$ Therefore, at least one issue pertinent to the topic can be encountered in relevant literature. However, the topic of resources within the criminal justice system of Kuwait appears to be otherwise uncovered by recent and less recent literature, which limits the ability of the current study to draw conclusions on it.

\section{The Role of Article 50 in the System}

Article 50 of the Constitution which requires SOP, as well as cooperation of powers, states that "No Authority shall be allowed to waive all or part of its jurisdiction." ${ }^{.5}$ Therefore, the Article guarantees SOP and implies that each of the components of criminal justice of Kuwait must act in accordance with their authority. The significance of establishing SOP has already been mentioned, ${ }^{6}$ which suggests that the implications of Article 50 for the functioning of the criminal justice system should be notable and beneficial. However, as it was mentioned above, the cases when the authority of the elements of the criminal justice system wasunderdefined ${ }^{7}$ or waived do occur. ${ }^{8}$ Consequently, the literature indicates that Article 50 is not always followed, but following it is crucial for ensuring SOP and the lack of power abuse.

\section{Conclusion}

The significance of SOP is easily established by the literature, but criminal-matters SOP is less extensively covered. As a result of the present literature review, no studies that would consider the criminal justice SOP in Kuwait were found, but the research and reports on the aspects that can be included in the discussion were encountered. In particular, the majority of the significant aspects of the criminal justice system can be described relatively well, which offers the opportunity for analysis. Similarly, the diffusion of law has been discussed relatively extensively.Also,the issues experienced by the criminal justice system in Kuwait appear to have received some coverage. The fact that the topic is understudied limits the ability of the literature review to respond to the research questions, but still, the following conclusions can be made.

The history of the development of Kuwaiti legal system has defined its features and some of its problems. Kuwait had experienced the impact of British Jurisdictionfor a long period, but when the country gained independence from the United Kingdom in 1961, the civil law system, based on the Egyptian law, which, in turn, is developed in accordance with the French law, was established in the country in addition to traditional Islamic law.However, the hasty introduction of the new legislation, as well as some of its inefficiencies, and the introduction of Egyptian lawyers into the Kuwaiti legal system have caused some long-lasting issues. The Constitution of Kuwait requires SOP and independence of the judiciary while also granting the citizens all the necessary rights and proclaiming them equal in the eyes of the law. However, the mentioned issues, especially those related to transparency and red tape, might endanger those rights. Moreover, there is some evidence indicating that the independence of judiciary being limited legislatively. Apart from that, the literature on the topic indicates other inefficiencies in various elements of the criminal justice system of Kuwait.

As shown by Barkow's article, which is the framework of the present study, the development of criminal-matters SOP is a crucial element of Kuwaiti's democratisation, and it is an important guarantee of the protection of the freedoms and rights of Kuwaiti people, which is especially evident in the light of the issues and barriers mentioned above. As a result, the

\footnotetext{
1 Brown, supra (n 21) 8.

2 Jon Michaels, 'An Enduring, Evolving Separation of Powers' (2015) 115 Columbia Law Review 515, 515-597.

${ }^{3}$ Travis and Edwards, supra(n 55)at 22.

${ }^{4}$ Morison and Grimshaw, supra(n 71)at 7.

${ }^{5}$ Constitution of Kuwait, 1962, art. 50.

${ }^{6}$ Samuels (n 1) at 706; see also Clark, supra (n 15) 971, 971-989.

${ }^{7}$ Morison and Grimshaw, supra(n 71) at 7.

${ }^{8}$ Kuwait, Decree Law No. 23 of 1990: Regulation of the Judiciary Law, 1990, art. 2.
} 
proposed research aspires to investigate SOP, primarily by considering its constitutional and historical roots and discussing its effectiveness from the point of view of human rights' protection.

\section{References}

\section{Primary Sources}

[1] Constitution of Kuwait, 1962, art. 6-8, 31, 50-53, 56, 71-73, 80, 163-164, 167-169.

[2] His Highness Sheikh Naser Al-Mohammad Al-Ahmad Al-Sabah, Prime Minister, 'Statement Before The SixtyFifth Regular Session Of The United Nations General Assembly' (United Nations, 2010) http://www.sheikhnasser.org.kw/upload/files/en/pdf/Sept\%2024\%202010.pdf accessed 12 February 2017.

[3] Kuwait, Decree 23/1990, articles 32 and 35, 1990.

[4] Kuwait, Decree Law No. 23 of 1990: Regulation of the Judiciary Law, 1990, article 2.

[5] Kuwait, Decree Law No. 67 of 1980, 1980, articles 1-3, 61.

[6] Kuwait, Law No. 14 of 1973, 1973, articles 1-5.

[7] Kuwait, Law No. 16 of 1960 (as amended): Penal Code, article 184.

[8] Kuwait, Law No. 17 of 1960: Code of Criminal Procedure, 1960, articles 1-75.

[9] Kuwait, Law No. 31 of 1970: Act Amending the Provisions of the Penal Code (National Security Law), 1970, articles 1-58.

[10] Kuwait, Nationality Law, 1959, articles 1-5.

[11] Kuwait, Prison Regulation Act 26/1962, articles 17-18.

\section{Secondary Sources}

[1] Alhajeri M, 'Judiciary and the Administration of Justice in Building and Construction Disputes Under Kuwaiti Law' (2008) 22 Arab Law Quarterly 199-214.

[2] Alkarama Foundation, 'Kuwait: Report submitted to the Human Rights Committee in the context of the third periodic review of Kuwait' (Alkarama Foundation, 2016) http://tbinternet.ohchr.org/Treaties/CCPR/Shared\%20Documents/KWT/INT_CCPR_CSS_KWT_24051_E.pdf accessed 22 March 2017.

[3] Al-Mogatei M, 'Introducing Islamic Law in the Arab Gulf States: A Case Study of Kuwait' (1989) 4Arab Law Quarterly 138-148.

[4] Al-Qudsy A and Rahman A, 'Effective Governance in the Era of Caliphate 'Umar Ibn Al-Khattab (634-644)' (2011) 18 European Journal of Social Sciences 612-624.

[5] Alshenqeeti H, 'Interviewing as a Data Collection Method: A Critical Review' (2014) 3English Linguistics Research39-45.

[6] Al-Zumai F, 'Kuwait's Political Impasse and Rent-Seeking Behaviour: A Call for Institutional Reform' (Kuwait Programme on Development, Governance and Globalisation in the Gulf States, 2013) accessed 2 January 2016.

[7] Aristotle, Politics (H. Rackham [transl]) (Cambridge University Press, 1932).

[8] Ashworth A and Horder J, Principles of Criminal Law (OUP 2013).

[9] Ashworth A, 'Responsibilities, Rights, and Restorative Justice' (2002) 42 British Journal of Criminology 578-595.

[10] Ashworth A, Zedner L and Tomlin P, Prevention and the Limits of the Criminal Law (OUP Oxford 2013).

[11] Atanassow E, 'Colonization and Democracy: Tocqueville Reconsidered' (2017) 111 American Political Science Review 83-96.

[12] Azfar O and Nelson WR, 'Transparency, Wages, and the Separation of Powers: An Experimental Analysis of Corruption' (2007) 130 Public Choice 471-493.

[13] Barkow R, 'Separation of Powers and the Criminal Law' (2006) 58 Stanford Law Review 989-1054.

[14] Braun V and Clarke V, 'Using Thematic Analysis in Psychology' (2006) 3Qualitative Research in Psychology 77-101.

[15] Brown NJ, The Rule of Law in the Arab World, (Cambridge University Press 2006)

[16] Brown, NJ 'Mechanisms of Accountability in Arab Governance' (United Nations, 2001) accessed 18 December 2016

[17] Bruff H, Balance of Forces: Separation of Powers Law in the Administrative State.(Carolina Academic Press 2006).

[18] Burdett A, Records of Kuwait (Archive Editions 2003). 
[19] Carballo, A, 'The Law of the Dubai International Financial Centre: Common Law Oasis or Mirage within the UAE?' (2007) 21 Arab Law Quarterly 91-104.

[20] Casey M, The History of Kuwait (Greenwood Publishing Group 2007).

[21] Clark T, 'The Separation of Powers, Court Curbing, and Judicial Legitimacy' (2009) 53 American Journal of Political Science 971-989.

[22] Conway G, 'Recovering a Separation of Powers in the European Union' (2011) 17 European Law Journal 304322.

[23] Cordesman A, Bahrain, Oman, Qatar, And The UAE: Challenges of Security (Routledge 2018).

[24] Crystal J, 'Criminal Justice in the Middle East' (2001) 29 Journal of Criminal Justice 469-482.

[25] Crystal J, Kuwait: The Transformation of an Oil State (Routledge 2016).

[26] Cunliffe A, 'Crafting Qualitative Research' (2011) 14 Organizational Research Methods 647-673.

[27] Dajani O, 'The Middle East's Majority Problems: Minoritarian Regimes and the Threat of Democracy' (2015) 38 Ethnic and Racial Studies 2516-2533.

[28] Daugherty D, 'Separation of Powers and Abuses in Prosecutorial Discretion' (1988) 79 Journal of Criminal Law and Criminology 953-996.

[29] Dobinson I and Johns F, 'Qualitative Legal Research' in M McConville and W H Chui (eds), Research Methods for Law (Edinburgh University Press 2007).

[30] Edwards R and Holland J, What Is Qualitative Interviewing? (Bloomsbury 2013).

[31] Emmerson B, Ashworth A and Macdonald A, Human Rights and Criminal Justice (Sweet \& Maxwell 2012).

[32] Eriksson P and Kovalainen A, Qualitative Methods in Business Research (SAGE 2015).

[33] Executive Board of the United Nations Development Programme, the United Nations Population Fund and the United Nations Office for Project Services, 'Draft Country Programme Document for the State of Kuwait (20152018)' (United Nations, 2014) accessed 18 December 2016.

[34] Farran S, Gallen J and Rautenbach C, The Diffusion of Law: The Movement of Laws and Norms around the World (Routledge 2016).

[35] Frane A, Measuring National Innovation Performance (Springer 2014).

[36] Freedom House, 'Bahrain' (Freedom House, 2016) accessed 18 March 2018.

[37] Freedom House, 'Kuwait' (Freedom House, 2016) accessed 18 December 2016.

[38] Gillespie C, Bahrain (Infobase Publishing 2009).

[39] Goldoni M, 'Montesquieu and the French Model of Separation of Powers' (2013) 4 Jurisprudence 20-47.

[40] Gulf Cooperation Council, 'Member States' (Gulf Cooperation Council, 2018) accessed 18 March 2018.

[41] Hair J, Celsi M, Money A and Page M, Essentials of Business Research Methods(Routledge 2015).

[42] Haljan D, Separating Powers: International Law Before National Courts, (Springer 2013)

[43] Hall M, 'TheSemiconstrained Court: Public Opinion, The Separation Of Powers, And The U.S. Supreme Court's Fear Of Nonimplementation' (2013) 58 American Journal of Political Science 352-366.

[44] Hall MEK and Ura JD, 'Judicial Majoritarianism' (2015) 77 The Journal of Politics 818-832.

[45] Hatina M and Schumann C, Arab Liberal Thought after 1967 (Springer 2015)

[46] Herb M, The Wages of Oil (Cornell University Press 2014).

[47] Hijazi A, 'Kuwait: Development from a Semitribal, Semicolonial Society to Democracy and Sovereignty' (1964) 13 The American Journal of Comparative Law 428-438.

[48] Huneidi I, 'Twenty-Five Years of Civil Law System in Kuwait' (1986) 2Arab Law Quarterly 216-219.

[49] International Monetary Fund, Kuwait: Selected Issues and Statistical Appendix (International Monetary Fund 2012).

[50] Joyce M, Kuwait (Cass 1998).

[51] Kamali MH, 'Separation of Powers: An Islamic Perspective' (2014) 5/slam and Civilisational Renewal 471-488.

[52] Koven S, 'Separation of Powers, Rule of Law, and the Bush Administration' (2009) 11 Public Integrity 347-361.

[53] Lahman M, Ethics in social science research (Sage 2017).

[54] Liebesny H, The Law of the Near and Middle East: Readings, Cases, and Materials (SUNY Press 1975).

[55] Locke J, Two Treatises on Government (Industrial Systems Research 2009).

[56] Manning J, 'Separation of Powers as Ordinary Interpretation' (2011) 2 Harvard Law Review 1939-2040.

[57] Michaels J, 'An Enduring, Evolving Separation of Powers' (2013) 115 Columbia Law Review 515-597.

[58] Montesquieu C, The Spirit of Laws (Cosimo 2011). 
[59] Morison J and Grimshaw B, Investigation, Process and Legal Standards within the Criminal Justice System in Kuwait (Queen's University Belfast 2016).

[60] Mousavi M, 'A Comparative Study between Kuwait and Britain Level of Understanding the Scope of Free Speech in Both Countries' (2016) 7 International Journal of Educational Research and Reviews 880-888.

[61] Murphy A and Stoica A, 'Sovereignty: Constitutional and Historical Aspects' (2015) 2Bulletin of the Transilvania University of Braşov219-226.

[62] Nader F, 'Kuwait: Human Rights Under the Constitution' (2000) 7 YB Islamic \& Middle EL 267-270.

[63] Nelson K and Ringsmuth E, 'Inter-Institutional Dynamics: Assessments of the Supreme Court in a Separation of Powers Context' (2012) 35 Political Behavior357-382.

[64] Örücü E, 'What is a Mixed Legal System: Exclusion or Expansion' (2008) 12 Electronic Journal of Comparative Law 1-18.

[65] O'Shea M, Spilling M and Cavendish M, Kuwait (Routledge 2010).

[66] Oxford Business Group, Kuwait, 2013 (Oxford Business Group 2013).

[67] Palmer VV, 'Mixed legal system' in Bussani and Matei (eds), The Cambridge Companion to Comparative Law ( Oxford University Press, 2012)

[68] Reda A, 'A Summary of the Legal and Judicial System in the State of Kuwait' (1991) 6Arab Law Quarterly 267279.

[69] Rehman A, Ibrahim M and Bakar I, 'The Concept of Independence of Judiciary in Islam' (2013) 4International Journal of Business and Social Science 67-75.

[70] Rosiny S, 'Power Sharing in Syria: Lessons from Lebanon's Taif Experience' (2013) 20 Middle East Policy 4155.

[71] Saikal A, 'Authoritarianism, Revolution and Democracy: Egypt and Beyond' (2011) 65 Australian Journal of International Affairs 530-544.

[72] Salameh M and Al-sharah M, 'Kuwait's Democratic Experiment: Roots, Reality, Characteristics, Challenges, and the Prospects for the Future' (2006) 5Journal of Middle Eastern and Islamic Studies (in Asia) 57-81.

[73] Samuels D, 'Separation of Powers' in C Boix and SC Stokes (eds), The Oxford Handbook of Comparative Politics (OUP 2009)

[74] Schleiter P and Belu V, 'The Decline of Majoritarianism in the UK and the Fixed-term Parliaments Act' (2016) 69 Parliamentary Affairs 36-52.

[75] Selvik K and Alnajjar G, 'Kuwait: The Politics of Crisis' in K Selvik and BO Utvik (eds), Oil States in the New Middle East: Uprisings and stability (Routledge 2015)

[76] Socarras M, 'Judicial Modification of Statutes: A Separation of Powers Defense of Legislative Inefficiency' (1985) 4 Yale Law \& Policy Review 228-250.

[77] Steiner E, French Law (OUP 2018).

[78] Stepan A, Linz J and Minoves J, 'Democratic Parliamentary Monarchies' (2014) 25 Journal of Democracy 3551

[79] The National Assembly of Kuwait, 'The Progress of Democracy in the State of Kuwait' (National Assembly, 2011) accessed 11 February 2017.

[80] Travis L and Edwards B, Introduction to Criminal Justice (Routledge 2014).

[81] Treisman D, 'The Causes of Corruption: A Cross-National Study' (2000) 76 Journal of Public Economics 399457.

[82] Tribe LH, 'Transcending the Youngstown Triptych: A Multidimensional Reappraisal of Separation of Powers Doctrine' (2016) 126 The Yale Law Journal Forum 86-106.

[83] Ulrichsen K, 'Politics and Opposition in Kuwait: Continuity and Change' (2014) 4Journal of Arabian Studies 214230.

[84] United Nations, 'A Kyoto Protocol to the United Nations Framework Convention on Climate Change' (United Nations, 2018) accessed 18 March 2018.

[85] United Nations, 'Charter of the United Nations and Statute of the International Court of Justice' (United Nations, 2018) accessed 18 March 2018.

[86] United Nations, 'Convention against Torture and Other Cruel, Inhuman or Degrading Treatment or Punishment' (United Nations, 2018) accessed 18 March 2018.

[87] United Nations, 'The UN System in Kuwait' (United Nations, 2018) accessed 18 March 2018. 
[88] USA International Business Publications, Kuwait Justice System and National Police Handbook (USA International Business Publications 2007).

[89] Vaismoradi $\mathrm{M}$, Jones $\mathrm{J}$, Turunen $\mathrm{H}$ and Snelgrove $\mathrm{S}$, 'Theme development in qualitative content analysis and thematic analysis' (2016) 6 Journal of Nursing Education and Practice 100-110.

[90] Waldron J, 'Separation of Powers in Thought and Practice' (2013) 54 Boston College Law Review 433-448.

[91] Williamson M, 'The diffusion of Western Legal Concepts in Kuwait: Reflections on the State, the Legal System, and Legal Education' in S Farran, J Gallenand C Rautenbach(eds), The Diffusion of Law: The Movement of Laws and Norms around the World (Routledge 2016).

[92] Zahlan R, The Making of the Modern Gulf States (Routledge 2016).

\section{Media Interviews}

[1] Aljazeera Chanel, Program name is; the "Interview" published by Aljazeera on Mar 9, 2017. https://www.youtube.com/watch?v=GknsmBRss70 